\title{
Field trials of various models of the pyramid trap on Glossina palpalis in the Congo
}

\author{
Jean-Paul Gouteux ${ }^{1}$ \& Dominique Sinda \\ ORSTOM, Institut français de recherche scientifique pour le développement en coopération, B.P. 181, \\ Brazzaville, Congo ${ }^{1}$ Present address: Centre ORSTOM, B.P. 893, Bangui, RCA \\ Accepted: October 24, 1989
}

Key words: Glossina palpalis, trapping, attractiveness, efficiency, pyramid trap, Congo

\begin{abstract}
Preliminary trials of 12 models of the pyramid trap were carried out in the Congo on Glossina palpalis palpalis (Robineau-Desvoidy) using Latin square designs. The models were compared with the standard trap with which they differed either in the shape of the pyramid, the addition of a royal blue cloth skirt, or the pattern of the blue-black screen. A decrease in height and/or volume of the pyramid significantly reduced the capture rate. The standard tetrahedral pyramid was significantly superior to both the regular tetrahedral and the trihedral pyramid. The addition of a royal blue cotton skirt modified both the attractiveness and effectiveness of the trap. However, although the attractiveness was probably increased, the skirt may have deterred the flies from entering the pyramid; the best results were obtained with the largest openings. The modification of the blue-black screen pattern may be a way to increase the attraction of flies to the trap. Although no model was found to be significantly superior to the standard, certain gave interesting results which should be investigated further.
\end{abstract}

\section{Introduction}

After decades of tsetse control by methods which often had disastrous effects on the environment (reviewed by Matthiessen \& Douthwaite, 1985), trapping represents a new stage, offering methods which are both ecologically clean and accessible to the human populations directly involved, that is, the African rural communities (Vale et al., 1988; Brightwell et al., 1987).

The pyramid tsetse trap (Gouteux \& Lancien, 1986; Fig. 1: S) is based on the attractive effect of blue-black screens (which was observed in the Congo by Dagnogo \& Gouteux in 1985 and Gouteux \& Noireau in 1986) combined with the simplicity of the pyramid shape. Lancien adopted this shape in his 'monoconical' trap (Lancien, 1981) but did not obtain satisfactory catches of flies (Dagnogo \& Gouteux, 1985). Briefly, the screens of contrasting colours are the attracting part of the trap, and the pyramid-shaped cover made of mosquito netting together with the apical capture bag forms the catching device. During early experiments the height of the screens inside the pyramid appeared to play an important role in the efficacy of the trap (Gouteux \& Lancien, 1986). Although large scale control trials conducted in the Congo confirmed the effectiveness of this model (Gouteux et al., 1986; 1987; Gouteux \& Sinda, 1989), it was considered worth assessing the role of other components such as the size and shape of the pyramid, and the pattern of

\section{ORSTOM Fonds Documentaire}


the blue-black screens. Indeed, certain modifications may improve the cost-effectiveness of the standard trap. Various models were therefore designed and tested in the field and the results are presented here.

\section{Methods and materials}

Diagrams of the traps are shown in Fig. 1. The standard pyramid trap (S) consists of a mosquito net pyramid made up of four isosceles triangles (height $=84 \mathrm{~cm}$, base $=68 \mathrm{~cm}$, side $=90 \mathrm{~cm}$ ) and two crossed screens $100 \mathrm{~cm}$ wide (height inside the pyramid $=30 \mathrm{~cm}$, under the pyramid $=60 \mathrm{~cm}$ ). All the other pyramid traps were the same size except for trap $E$ in which the pyramid was made up of four equilateral triangles (side = $68 \mathrm{~cm}$ ) and trap T in which the pyramid was made up of three isosceles triangles (height $=90 \mathrm{~cm}$, base $=95 \mathrm{~cm}$, side $=100 \mathrm{~cm}$ ). The biconical trap $(\mathrm{X})$ was that described by Challier and Laveissière (1973). The traps with skirts (A to $G$ ) had two black screens and one band of royal blue
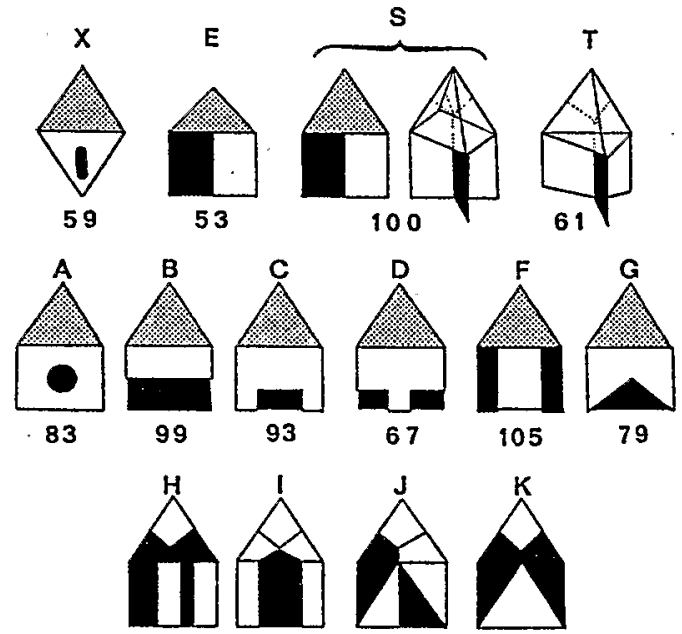

105

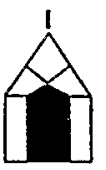

97
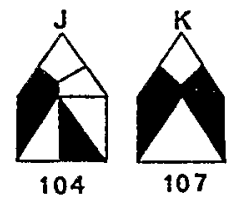

Fig. 1. Diagrams of traps tested in the Latin squares and results of all the catches for each trap expressed per 100 Glossina caught in the standard pyramid trap (S). Except for traps in the $\mathrm{H}-\mathrm{K}$ series, the screens are not shown inside the pyramid. E: equilateral pyramid trap, T: trihedral pyramid trap, X: biconical trap, A-G: skirt pyramid traps, H-K: various patterned pyramid traps. cloth bordering the bottom of the pyramid (the skirt) similar to Chorley's 'crinoline' (Chorley, 1933). The traps with a skirt had an opening of varying size and shape on each side. The traps $\mathrm{H}$ to $\mathrm{K}$ only differed from the standard in the pattern of the blue-black screen.

All the traps were made of loose-mesh mosquito netting, black muslin and royal blue cotton. They were held up with two detachable wooden rods of $100 \mathrm{~cm}$, crossed at the base of the pyramid and held in the screens by gussets. They were all used with plastic capture bags filled with kerosine in order to kill and preserve the flies (Gouteux et al., 1987). The trap is hung up in the trees by the capture bag.

The trials were carried out from June to October 1987 near the Niari River (Kimbédi: $4^{\circ} 17^{\prime} \mathrm{S}, 13^{\circ} 57^{\prime} \mathrm{E}$ ) on $\mathrm{G}$. palpalis palpalis. All 12 experiments ( $6+6$ duplicates) employed $6 \times 6$ or $5 \times 5$ Latin square designs (eight 6 , four 5). A log transformation was generally adequate to ensure

36

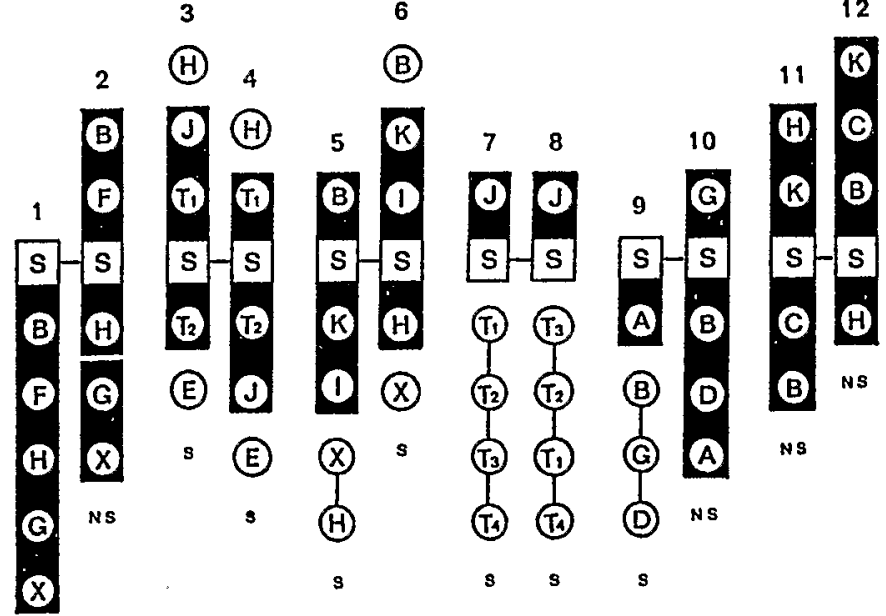

N S

Fig. 2. Each diagram component, numbered from 1 to 12 , corresponds with a Latin square. Position of traps present the total catches, increasing from bottom to top. Results of each Latin square analysis of variance are indicated (NS: no significant difference, $\mathrm{S}$ : significant difference at $5 \%$ confidence level. $F$ values in Table 1). According to Dunnett's Least Significant Difference method, traps isolated from the standard $(\mathrm{S})$ indicate significant difference with it. There is concordance between these two tests, except for the Latin square number 2 . 


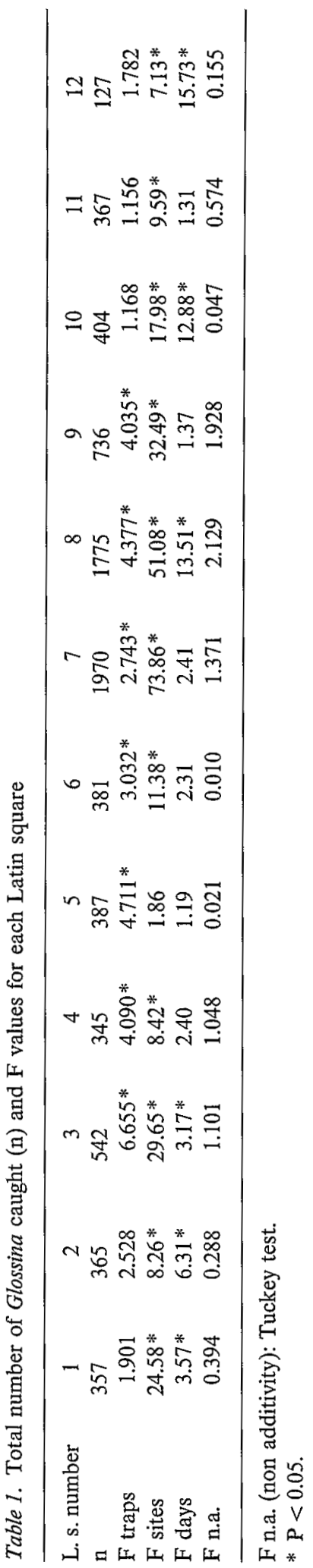

normality of the data. This was established by checking the independence of the variance and the mean. The Tukey test was used to check for additivity. Analysis of variance was then carried out and the significance (at $5 \%$ level) was ascertained by the $F$ test.

The results are expressed as the average number of tsetse captured per 100 individuals caught in the standard trap (which was used as a reference in each Latin square) and subjected to an overall analysis of variances. The difference of catches between the standard trap and the others was assessed by a Least Significant Difference method of Dunnett (in Dagnélie, 1975, p. 252).

During these experiments 7,756 G.p.palpalis were caught.

\section{Results}

The mean catches over all tests are shown in Fig. 1. An overall variance analysis present a significant difference between this 14 traps $(\mathrm{F}=2.82,0.025>\mathrm{P}>0.001)$. Models $\mathrm{E}, \mathrm{T}$ and $\mathrm{X}$ are significantly less efficient than the standard according with the Dunnett's method (Least Significant Difference $=33.2$ ). The modifications in the shape of the pyramid resulted in significantly less efficient traps (models $\mathrm{E}$ and $\mathrm{T}$ ) compared with the standard model S. On the other hand, most traps with skirts or modifications in the screen pattern gave results which were as good or slightly better than the standard, except for models $D$ and $G$, which were notably less efficient. Considered separately, only 7 of the 12 Latin squares showed significant differences, and the significant superiority of the standard model over the models $\mathrm{T}, \mathrm{X}, \mathrm{E}$ was shown in 2 squares each, and of the standard over $D$ and $G$ in $I$ square each. However the results were variable with models $B$ and $H$, which were significantly more or less efficient than the standard in different Latin squares (Fig. 2, Table 1). 


\section{Discussion}

The pyramid trap was originally designed to be effective enough for use as a vector control trap without olfactory attracting agents or insecticide impregnation. The aim was to achieve maximum simplicity for use by rural communities. The trap is thus extremely simple and cheap. The cost is reduced further in model $\mathrm{E}$ in which the mosquito netting is easier to cut and fix (less netting required) and in model $\mathrm{T}$ in which the quantity of cloth required for the screens is reduced without important change of the visible surface.

The effectiveness of this type of trap is due both to the visual attractive effect for the tsetse and the ability to draw the flies inside to be caught in the capture device. There is thus a dual requirement, first to attract the flies from afar, then to lure them into the trap itself. Furthermore, once inside the pyramid net the tsetse must be drawn up towards the capture bag and not be able to escape easily. This quality was defined by Hargrove (1977) as 'efficiency' of the trap as opposed to its attractiveness. The modifications in the shape of the pyramid tested here did not alter the visible surface of the screen, so the visual attractiveness of the traps was largely preserved. However, these traps ( $\mathrm{E}$ and $\mathrm{T}$ ) were considerably less efficient. The pyramid of model $E$ was probably not high enough to prevent a considerable proportion of the flies escaping. The pyramid of model $\mathrm{T}$ may have lacked volume thus preventing easy access of the flies.

The choice of the colours blue and black may appear rather limited. However, since the discovery in the field of the attractiveness of royal blue for the tsetse (Challier et al., 1977) and the later confirmation of the importance of this shade of blue (Gouteux et al., 1981) including the measurement of spectral reflectivity (Green \& Flint, 1986), the attractive effect of this colour on the species of the palpalis group is now well established. The combination with the colour black, an essential feature of the screen-trap (Gouteux \& Noireau, 1986), contributes clearly to the high efficacy of this model and also accounts for the efficiency of the pyramid trap. The advantage of the blue and black combination was subsequently confirmed for the palpalis group and also for the morsitans group (Merot \& Filledier, 1985; CRTA, 1986, 1987). The blue screen appears to be mainly attractive, whereas the black seems to induce the landing response (Green, 1986; CRTA, 1986). Hence, a modification in the pattern of these two colours might modify both the attractiveness and the efficiency. The replacement of the crossed blue-black screens by a blue skirt and two black screens has a bearing on these two aspects. In order to distinguish attractiveness from efficiency, electrified nets should be used (Vale \& Hargrove, 1979). Nevertheless, to approach this problem pragmatically, the only data that actually is of interest is the number of flies collected in the catching-killing device (providing a direct efficiency measure). It has been shown that the effectiveness of the biconical trap (Challier et al., 1977) was strictly proportional to its size, and thus to the visible surface of the blue cloth forming the lower cone (Gouteux et al., 1981; Dagnogo \& Gouteux, 1985). However, the traps $A, D$ and $G$, which presented the largest visible blue surface in the series $A-G$, yielded the worst score (Fig. 1). This suggests that the skirt bordering the pyramid somewhat hinders the access of the flies. Indeed, traps B and F, in which the skirts had the largest openings, yielded the best score, whereas the opening was the smallest in trap A. The trap D, in which the opening was both small and lateral, yielded the worst score. These findings may account for the superiority of the pyramid trap over the biconical trap (model $X)$ observed here and in various comparative experiments (Gouteux \& Lancien, 1986) since the biconical trap has small openings. The promising results obtained with some of the skirt-models provide a possible alternative. Similarly, the modification in the blue-black screen pattern showed interesting results. In particular, the results for the trap $\mathrm{H}$ with the extra blue-black band and for the traps $\mathbf{J}$ and $\mathbf{K}$, suggest that attraction to the screen or into the pyramid might be increased. Further research could be carried out in this field. 


\section{Conclusion}

In the control of tsetse flies, a vector of trypanosomiasis in man and domestic animals, the standard pyramid trap represents considerable progress as it is easy to use at community level.

Although none of the models tried here was significantly more effective than the standard, improvements are always possible. The pyramid trap is a stage in ever-evolving research into trapping. Its use will be extended to other tsetse species (Slingenbergh, Kangwagye, personal communications) and it should be modified and adapted accordingly. These experiments suggest some ways for this to be undertaken.

\section{Acknowledgements}

This work received financial support from the UNDP/World Bank/WHO Special Programme for Research and Training in Tropical Diseases (TDR id: 850035). We thank Marc Jarry for this pertinent advice.

\section{Résumé}

Essais de différents modèles du piège pyramidal sur Glossina palpalis au Congo

Des essais de 12 variants du piège pyramidal ont été réalisés au Congo selon le protocole expérimental des carrés latins, sur Glossina palpalis palpalis (Rob.-Desv.). Les variants ont tous été comparés au modèle standard dont ils diffèrent soit par la forme de la pyramide, soit par l'adjonction d'une juppe de tissu bleu, soit par la recombinaison des parties bleues et noires des écrans. Les résultats ont montré le rôle particulier de ces différents composants du piège au niveau de l'attraction et de l'efficacité à la capture. Les modifications de la hauteur et du volume de la pyramide ont diminué significativement l'efficacité du système de capture, soit en rendant plus difficile l'accès de ce système au tsétsé, soit en leur facilitant la sortie de la pyramide. L'addition d'une jupe de tissu bleu modifie ces deux aspects à la fois, mais, si elle augmente probablement l'attractivité, la jupe de certains modèles gène la pénétration des mouches à l'intérieur de la pyramide. Le réagencement de la couleur bleue et noire des écrans pourrait accroître l'attraction de la mouche ou favoriser son ascension. Bien qu'aucun modèle ne soit apparu significativement supérieur au standard, certains de ceux-ci ont donné des résultats intéressants. Ces modifications constituent donc des voies à explorer, notamment en confrontant ces modèles avec d'autres espèces de tsétsé et dans d'autres environements.

\section{References}

Brightwell, R., R. D. Dransfield, C. Kyorku, T. K. Golder, S. A. Tarimo \& D. Mungai, 1987. A new trap for Glossina pallidipes. Trop. Pest Manag. 33: 151-159.

Challier, A., M. Eyraud, A. Lafaye \& C. Laveissière, 1977. Amélioration du rendement piège biconique pour glossines (Diptera: Glossinidae) par l'emploi d'un cône inférieur bleu. Cah. ORSTOM sér. Ent. méd. Parasit. 15: 283-286.

Chailier, A. \& C. Laveissière, 1973. Un nouveau piège pour la capture des glossines (Glossina: Diptera, Muscidae): description et essais sur le terrain. Cah. ORSTOM sér. Ent. méd. Parasit. 11: 251-262.

Chorley, C. W., 1933. Traps for tsetse flies of the 'crinoline' and 'ventilator' forms. Bull. Ent. Res. 24: 315-317.

CRTA, 1986. Rapport d'activité 1985. Centre de recherches sur les trypanosomoses animales, Bobo-Dioulasso, Burkina, 103 pp.

CRTA, 1987. Rapport d'activité 1986. Centre de recherches sur les trypanosomoses animales, Bobo-Dioulasso, Burkina, 73 pp.

Dagnelie, P., 1975. Théorie et méthodes statistiques. Applications agronomiques. Vol. 2, Presses Agronomiques de Gembloux, éd. Vander-oyez, Belgique. pp. 252-253.

Dagnogo, M. \& J. P. Gouteux, 1985. Comparaison de différents pièges à tsétsé (Diptera, Glossinidae) en Côte d'Ivoire et au Congo. Rev. Elev. Méd. vét. Pays trop. 38: $371-378$.

Gouteux, J. P., A. Challier \& C. Laveissière, 1981. Modifications et essais du piège à glossines (Diptera: Glossinidae) Challier-Laveissière. Cah. ORSTOM sér. Ent. méd. Parasit. 19: 87-99.

Gouteux, J. P., P. Bansimba, N. Bissadidi \& F. Noireau, 1987. La prise en charge de la lutte contre les tsétsé par les communautés rurales: premiers essais dans cinq villages congolais. Ann. Soc. belge Méd. trop. 67: 37-49.

Gouteux, J. P. \& J. Lancien, 1986. Le piège pyramidal à tsétsé (Diptera: Glossinidae) pour la capture et la lutte. 
Essais comparatifs et description de nouveaux systèmes de capture. Trop. Med. Parasit. 37: 61-6́6.

Gouteux, J. P. \& F. Noireau, 1986. Un nouvel écran-piège pour la lutte anti-tsétsé. Description et essais dans un foyer congolais de trypanosomiase humaine. Entomol. exp. appl. 41: 291-297.

Gouteux, J. P., F. Noireau, D. Sinda \& J. L. Frezil, 1986. Essais du piège pyramidal contre Glossina palpalis palpalis (Rob.-Desv.) dans le foyer du Niari (Région de la Bouenza, République Populaire du Congo). Cah. ORSTOM sér. Ent. méd. Parasit. 23: 181-190.

Gouteux, J. P. \& D. Sinda, 1989. Community participation in the control of tsetse flies. Large scale trials using the pyramid trap in the Congo. Trop. Med. Parasit. 40. in press.

Green, C. H., 1986. Effects of colours and synthetic odours on the attraction of Glossina pallidipes and $G$. morsitans to traps and screens. Phys. Ent. 11: 411-421.

Green, C. H. \& S. Flint, 1986. An analysis of colour effects in the performance of the $\mathrm{F} 2$ trap against Glossina pallidipes Austen and $G$. morsitans morsitans Westwood (Diptera: Glossinidae). Bull. ent. Res. 76: 409-418.
Hargrove, J. W., 1977. Some advances in the trapping of tsetse (Glossina spp.) and other flies. Ecol. Entomol. 2: 123-137.

Lancien, J., 1981. Description du piège monoconique utilisé pour l'élimination des glossines en République Populaire du Congo. Cah. ORSTOM sér. Ent. méd. Parasit. 19: 235-238.

Merot, P. \& J. Filledier, 1985. Efficacité contre Glossina morsitans submorsitans d'écrans de différentes couleurs avec ou sans adjonction de panneaux en moustiquaire noire. Rev. Elev. Med. vét. Pays trop. 38: 64-71.

Matthiessen, P. \& B. Douthwaite, 1985. The impact of tsetse fly control campaigns on African wildlife. Oryx 19: 202-209.

Vale, G. A. \& J. W. Hargrove, 1979. A method of studying the efficiency of traps for tsetse flies (Diptera: Glossinidae) and other insects. Bull. ent. Res. 69: 183-193.

Vale, G. A. \& D. F. Lovemore, S. Flint \& G. F. Cockbill, 1988. Odour-baited targets to control tsetse flies, Glossina spp. (Diptera: Glossinidae), in Zimbabwe, Bull. ent. Res. 78: 31-49. 